\title{
Bioaccumulation of organochlorine pesticides in the liver of birds from Boraphet wetland, Thailand
}

\author{
Rattanawat Chaiyarat $^{\mathrm{a}, *}$, Chadaporn Sookjam ${ }^{\mathrm{a}}$, Kairat Eiam-Ampai ${ }^{\mathrm{b}}$, Praneet Damrongphol $^{\mathrm{c}, \mathrm{d}}$ \\ a Wildlife and Plant Research Centre, Faculty of Environment and Resource Studies, Mahidol University, \\ 999 Phuthamonthon 4, Salaya, Phuthamonthon, Nakhon Pathom 73170 Thailand \\ b Bueng Boraphet Wildlife Research Station, Department of National Parks Wildlife and Plant Conservation, \\ Nakhon Sawan 60000 Thailand \\ c Department of Biology, Faculty of Science, Mahidol University, Bangkok 10400 Thailand \\ d Centre for Environmental Health, Toxicology and Management of Chemicals, \\ CHE:33328 Si Ayutthaya Road, Bangkok 10400 Thailand
}

*Corresponding author, e-mail: rattanawat.cha@mahidol.ac.th

Received 4 Jul 2013

Accepted 14 May 2014

\begin{abstract}
The accumulation of toxic and persistent organochlorine pesticides (OCPs) in the liver tissues of nine species of birds collected from the wetland, Bueng Boraphet, central Thailand was studied during April 2007 to September 2010. Contamination at different trophic levels (in carnivorous, omnivorous, and insectivorous birds) was also analysed. The study indicates that birds in the Boraphet wetland are still subject to OCP contamination. Total dichlorodiphenyltrichloroethane and metabolites ( $\mathrm{DDDTs}$ ) and total aldrin ( $\Sigma$ ALD) accumulated the most, followed successively by total hexachlorocyclohexanes $(\Sigma \mathrm{HCH})$ and total chlordane compounds ( $\Sigma \mathrm{CHL})$. Carnivorous birds were at highest risk of contamination by OCPs due to their highest trophic level. Omnivorous birds were contaminated with moderate levels of $\Sigma$ ALD and $\Sigma \mathrm{HCH}$. The insecticide usage seems to be well managed, as insectivorous birds were the least contaminated, with only low concentrations of $\Sigma$ ALD and $\Sigma \mathrm{HCH}$. Regular monitoring of OCP contamination is recommended due to a continued usage of OCPs in agriculture around the Boraphet wetland.
\end{abstract}

KEYWORDS: contamination, DDT, ALD, HCH

\section{INTRODUCTION}

Extensive use of organochlorine pesticides (OCPs) in agriculture during past decades poses an environmental problem. Owing to their persistence and lipid solubility, OCPs have a high potential of accumulation in the adipose tissue exposed of organisms, and biomagnification in the food web. Birds are especially vulnerable to OCPs due to their widespread distribution and high rates of food consumption. Carnivorous species are at highest risk for OCP accumulation ${ }^{1}$. Furthermore, OCPs have been found to impact the breeding success of many bird species because they inhibit carbonic anhydrase activity and therefore lower the levels of calcium, which in turn leads to eggshell thinning and breakage ${ }^{2-5}$. OCPs may also affect other reproductive properties of birds, including the induction of male feminization ${ }^{6}$, inhibiting egglaying, decreasing clutch size ${ }^{7}$ and hatching success ${ }^{8}$, and inducing deformities of the embryos 6,7 .

OCPs were used extensively in Thailand until 1983; when many compounds were banned by the Thai government (www.thailand.ipm-info.org/ pesticides/pesticides_banned.htm). Despite restrictions and bans on the use of many OCPs, their bioaccumulation and detection in the egg yolk of birds at the Wat Tan-En Non-hunting Area, Phranakhon Si Ayutthaya province, central Thailand ${ }^{9}$, and in the aquatic food web at Klong Rangsit, Patum Thani province, central Thailand ${ }^{10}$ indicates either continual use or persistence of the compounds in the environment.

Boraphet wetland is located in Nakhon Sawan province, central Thailand $\left(15^{\circ} 40^{\prime}-45^{\prime} \mathrm{N}\right.$ and $100^{\circ}$ $\left.10^{\prime}-23^{\prime} \mathrm{E}\right)$. Lying at a maximum elevation of $24 \mathrm{~m}$ above sea level, it is the largest freshwater wetland in Thailand $\left(212 \mathrm{~km}^{2}\right)$, and is considered to be of international conservation importance ${ }^{11,12}$. The wetland encompasses a reservoir and surrounding agricultural areas. Its ecosystems include floodplains of the Chao Phraya River and its tributaries ${ }^{13}$. The reservoir is an important breeding ground for aquatic animals, particularly fish from the Chao Phraya River, because the river tributaries carry nutrients and sediments into the reservoir. The wetland also serves as a major habitat for wintering and nesting birds; holding more than 20000 birds of at least 187 species $^{13}$. 
Table 1 Locations of ten sampling sites in the Boraphet wetland.

\begin{tabular}{llll}
\hline Site & Location & Coordinates & Description \\
\hline 1 & Fai Kao & $15^{\circ} 41^{\prime} 58^{\prime \prime} \mathrm{N} 100^{\circ} 10^{\prime} 44^{\prime \prime} \mathrm{E}$ & Paddy fields \\
2 & Ko Wat & $15^{\circ} 42^{\prime} 14^{\prime \prime} \mathrm{N} 100^{\circ} 12^{\prime} 38^{\prime \prime} \mathrm{E}$ & Central lake area \\
3 & Ban Tha Din Daeng & $15^{\circ} 43^{\prime} 3^{\prime \prime} \mathrm{N} 100^{\circ} 13^{\prime} 17^{\prime \prime} \mathrm{E}$ & Fish farm \\
4 & Pluak Sung & $15^{\circ} 40^{\prime} 55^{\prime \prime} \mathrm{N} 100^{\circ} 13^{\prime} 33^{\prime \prime} \mathrm{E}$ & Communities \\
5 & Pramong Choeng Panit & $15^{\circ} 42^{\prime} 38^{\prime \prime} \mathrm{N} 100^{\circ} 16^{\prime} 21^{\prime \prime} \mathrm{E}$ & Paddy fields \\
6 & Laem Na - Ko Ta Ruang & $15^{\circ} 41^{\prime} 32^{\prime \prime} \mathrm{N} 100^{\circ} 16^{\prime} 12^{\prime \prime} \mathrm{E}$ & Central lake area \\
7 & Khlong Huai Hin & $15^{\circ} 40^{\prime} 2^{\prime \prime} \mathrm{N} 100^{\circ} 15^{\prime} 50^{\prime \prime} \mathrm{E}$ & Paddy fields and watermelon farm \\
8 & Laem Ta Seng Research Station & $15^{\circ} 42^{\prime} 5^{\prime \prime} \mathrm{N} 100^{\circ} 17^{\prime} 12^{\prime \prime} \mathrm{E}$ & Central lake area and no farming \\
9 & Noen Rakang & $15^{\circ} 41^{\prime} 9^{\prime \prime} \mathrm{N} 100^{\circ} 17^{\prime} 33^{\prime \prime} \mathrm{E}$ & Paddy fields \\
10 & Khlong Khao Phanom Set & $15^{\circ} 41^{\prime} 44^{\prime \prime} \mathrm{N} 100^{\circ} 19^{\prime} 53^{\prime \prime} \mathrm{E}$ & Paddy fields \\
\hline
\end{tabular}

Although the Boraphet wetland is a major waterbird site, there has been only scant pesticide monitoring. Pesticides used in surrounding rice paddies and farmland can accumulate in the reservoir, and in aquatic organisms to become biomagnified through the food chain ${ }^{14,15}$. Collecting live specimens is prohibited; so that previous studies have mostly been confined to analysis of pesticide residues in carcasses.

The present study was carried out as a subproject of the Surveillance and Protection of All Viruses in Wild Birds Programme, authorized by the Department of National Parks, Wildlife and Plant Conservation of Thailand (DNP). The programme carried out surveys of viral infections among wild birds following outbreaks of the high pathenogenicity avian influenza during 2005-2008. The present study investigated the accumulation of OCPs in the liver tissues of birds collected under the above programme to assess environmental contamination by pesticides. Furthermore, the concentrations of OCPs in carnivorous, omnivorous, and insectivorous birds were analysed to evaluate OCP contamination at different trophic levels.

\section{MATERIALS AND METHODS}

A total of 49 birds comprising nine species were captured during April 2007 - March 2010 in 10 different sites in the Boraphet wetland (Table 1 and Fig. 1) using mist-nets. The samples of a particular species from different locations were analysed and reported as one group. Captured birds were categorized according to their feeding habits into three groups: (1) carnivorous birds that fed on animals such as fish, prawns, and frogs: Little Cormorant (Phalacrocorax niger), Yellow Bittern (Ixobrychus sinensis), and Long-tailed Shrike (Lanius schach); (2) omnivorous birds that fed on young leaves, flowers, grains, insects, shrimp, and fish: Pheasant-tailed Jacana (Hydrophasianus chirurgus), Asian Pied Starling (Sturnus contra), and Purple Swamphen (Porphyrio porphyrio); and (3) insectiv-

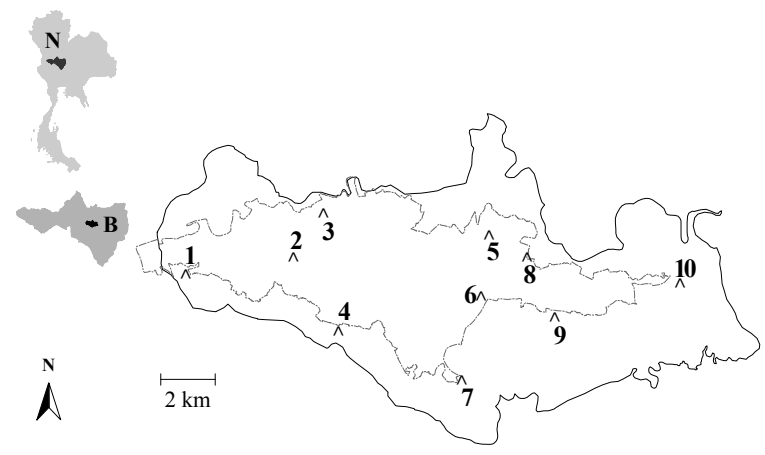

Fig. 1 Locations of sampling sites in Boraphet wetland nonhunting area (B), Nakhon Sawan province (N), Thailand: Fai Kao (1), Ko Wat (2), Ban Tha Din Daeng (3), Pluak Sung (4), Pramong Choeng Panit (5), Laem Na-Ko Ta Rueang (6), Khlong Huai Hin (7), Laem Ta Seng Research Station (8), Noen Rakang (9), Khlong Khao Phanom set (10).

orous birds: Striated Grassbird (Megalurus palustris), Streak-eared Bulbul (Pycnonotus blanfordi), and Dusky Warbler (Phylloscopus fuscatus).

After collection, samples were prepared by a veterinary physician from DNP, following animal welfare regulations. The abdominal cavity of each bird was cut open. The liver was resected, weighed, and individually stored at $-20^{\circ} \mathrm{C}$ for further analysis.

The protocol for analysis was carried out with a modification of the method suggested by Cid et $\mathrm{al}^{16}$. Liver samples were defrosted, thawed, and washed in deionized water. Each bird was prepared separately. Each sample was homogenized in a blender with anhydrous $\mathrm{Na}_{2} \mathrm{SO}_{4}$ in a ratio of 1:4. The samples were then extracted with $100 \mathrm{ml}$-hexane and acetone $(4: 1 \mathrm{v} / \mathrm{v})$ using soxhlet extractors for $2 \mathrm{~h}$. Each extract was dried under a nitrogen stream and then redissolved in $2 \mathrm{ml}$ of n-hexane. Precisely $1 \mathrm{ml}$ of extract from the chloroform layer was drawn to determine the lipid content by gravimetry ${ }^{17}$. The 
Table 2 The liver mass and the concentration of each OCP isomer in birds of the Bueng Boraphet wetland.

\begin{tabular}{|c|c|c|c|c|c|c|c|c|c|c|c|c|}
\hline & $\begin{array}{l}\text { Phalacro- } \\
\text { corax } \\
\text { niger }\end{array}$ & $\begin{array}{c}\text { Ixobrychus } \\
\text { sinensis }\end{array}$ & $\begin{array}{l}\text { Lanius } \\
\text { schach }\end{array}$ & Carnivores $^{\mathrm{b}}$ & $\begin{array}{l}\text { Hydro- } \\
\text { chirurgus } \\
\text { phasianus }\end{array}$ & $\begin{array}{l}\text { Sturnus } \\
\text { contra }\end{array}$ & $\begin{array}{l}\text { Porphyrio } \\
\text { porphyrio }\end{array}$ & Omnivores $^{b}$ & $\begin{array}{l}\text { Megalurus } \\
\text { palustris }\end{array}$ & $\begin{array}{l}\text { Pycnonotus } \\
\text { blanfordi }\end{array}$ & $\begin{array}{l}\text { Phyllo- } \\
\text { scopus } \\
\text { fuscatus }\end{array}$ & Insectivores $^{\mathrm{b}}$ \\
\hline $\begin{array}{l}\text { Common } \\
\text { name }\end{array}$ & $\begin{array}{c}\text { Little } \\
\text { Cormorant }\end{array}$ & $\begin{array}{l}\text { Yellow } \\
\text { Bittern }\end{array}$ & $\begin{array}{l}\text { Long- } \\
\text { tailed } \\
\text { Shrike }\end{array}$ & & $\begin{array}{l}\text { Pheasant- } \\
\text { tailed } \\
\text { Jacana }\end{array}$ & $\begin{array}{c}\text { Asian } \\
\text { Pied } \\
\text { Starling }\end{array}$ & $\begin{array}{c}\text { Purple } \\
\text { Swamphen }\end{array}$ & & $\begin{array}{l}\text { Striated } \\
\text { Grassbird }\end{array}$ & $\begin{array}{l}\text { Streak- } \\
\text { eared } \\
\text { Bulbul }\end{array}$ & $\begin{array}{c}\text { Dusky } \\
\text { Warbler }\end{array}$ & \\
\hline Number of samples & 6 & 8 & 6 & 20 & 10 & 4 & 3 & 17 & 5 & 3 & 4 & 12 \\
\hline Liver mass (g) & $1.3 \pm 0.7$ & $1.4_{ \pm 1.0}$ & $0.3 \pm 0.1$ & $1.2 \pm 0.8$ & $1.4_{ \pm 1.0}$ & $1.9 \pm 0.0$ & $1.5_{ \pm 0.7}$ & $1.5_{ \pm 0.7}$ & $0.7 \pm 0.4$ & $1.1_{ \pm 0.4}$ & $0.2 \pm 0.1$ & $0.7_{ \pm 0.5}$ \\
\hline Lipid determination $(\% \mathrm{w} / \mathrm{w})$ & 70 & 80.5 & 33.5 & $33.5-80.5$ & 70.5 & 79.5 & 73.5 & $70.5-79.5$ & 36 & 53.5 & 9 & $9-53.5$ \\
\hline $4,4^{\prime}-\mathrm{DDD}$ & $74.2^{\mathrm{a}}$ & $59_{ \pm 81}^{[116.5]}$ & ND & $27.2 \pm 6.7$ & ND & ND & $8.2^{\mathrm{a}}$ & $2.7_{ \pm 0.4}^{[8.2]}$ & ND & ND & ND & ND \\
\hline $4,4^{\prime}-\mathrm{DDE}$ & $9.8_{ \pm 1.1}^{[10.6]}$ & $152_{ \pm 209}^{[300.7]}$ & $0.6^{\mathrm{a}}$ & $42 \pm 15$ & ND & $0.2^{\mathrm{a}}$ & ND & $<0.1 \pm 0.0$ & ND & ND & $0.4^{\mathrm{a}}$ & $<0.1 \pm 0.0$ \\
\hline $4,4^{\prime}-\mathrm{DDT}$ & $159.6^{\mathrm{a}}$ & ND & ND & $26.6_{ \pm 7.9}$ & ND & ND & ND & ND & ND & ND & ND & ND \\
\hline Aldrin & $9.1_{ \pm 0.1}^{[9.2]}$ & $11_{ \pm 15}^{[21.3]}$ & $1.3_{ \pm 1.9}^{[3.5]}$ & $6.5_{ \pm 1.0}$ & $3.0_{ \pm 3.7}^{[7.3]}$ & ND & $11.0_{ \pm 0.81}^{[11.5]}$ & $8.2 \pm 0.9$ & $9_{ \pm 11}^{[17]}$ & $4.3^{\mathrm{a}}$ & $0.8_{ \pm 1.4}^{[2.4]}$ & $5.7 \pm 1.4$ \\
\hline Dieldrin & ND & $6.7^{\mathrm{a}}$ & ND & $0.8_{ \pm 0.3}$ & ND & ND & $60_{ \pm 75}^{[112.3]}$ & $39.7 \pm 6.5$ & ND & ND & ND & ND \\
\hline$\alpha$-endosulphan & ND & ND & ND & ND & $4.7^{\mathrm{a}}$ & $0.2^{\mathrm{a}}$ & ND & $0.5_{ \pm 0.2}$ & ND & ND & ND & ND \\
\hline$\beta$-endosulphan & $119.4^{\mathrm{a}}$ & $178_{ \pm 238}^{[346.5]}$ & ND & $64_{ \pm 18}$ & ND & ND & ND & ND & ND & ND & ND & ND \\
\hline endosulphan sulphate & ND & $24_{ \pm 19}^{[48.6]}$ & ND & $12.1 \pm 2.8$ & ND & ND & ND & ND & $27^{\mathrm{a}}$ & ND & ND & $5.4_{ \pm 2.2}$ \\
\hline endrin & ND & $2.7^{\mathrm{a}}$ & $0.3^{\mathrm{a}}$ & $0.4_{ \pm 0.1}$ & ND & ND & ND & ND & $24.7^{\mathrm{a}}$ & ND & ND & $4.9_{ \pm 2.0}$ \\
\hline endrin aldehyde & ND & ND & ND & ND & ND & $8.6^{\mathrm{a}}$ & $11.6^{\mathrm{a}}$ & $3.9 \pm 0.8$ & ND & ND & ND & ND \\
\hline$\alpha-\mathrm{HCH}$ & $66.4^{\mathrm{a}}$ & $3.7_{ \pm 5.1}^{[9.6]}$ & $0.3^{\mathrm{a}}$ & $12.5_{ \pm 3.3}$ & $0.9_{ \pm 1.7}^{[4.4]}$ & $0.4_{ \pm 0.3}^{[0.8]}$ & ND & $0.9 \pm 0.2$ & $6^{\mathrm{a}}$ & ND & ND & $1.2 \pm 0.5$ \\
\hline$\beta-\mathrm{HCH}$ & ND & $1.3_{ \pm 0.3}^{[1.5]}$ & $3.3_{ \pm 5.7}^{[11.8]}$ & $2.5 \pm 0.5$ & $11_{ \pm 18}^{[31.5]}$ & $21.1^{\mathrm{a}}$ & ND & $0.9_{ \pm 2.1}$ & $30.4_{ \pm 0.0}^{[30.4]}$ & ND & ND & $6.1 \pm 2.5$ \\
\hline$\gamma-\mathrm{HCH}$ & $18_{ \pm 21}^{[41.8]}$ & $6.5^{[10]}$ & $0.3^{[0.4]}$ & $11.2 \pm 2.1$ & ND & $\begin{array}{r}5.7^{[16.3]} \\
\pm 9.2\end{array}$ & $\begin{array}{c}19^{[35.3]} \pm 23 \\
.51\end{array}$ & $16.9_{ \pm 2.2}$ & $1.5^{[2.3]}$ & $1.5_{ \pm 0.6}^{[1.9]}$ & $0.1_{ \pm 0.1}^{[0.2]}$ & $1.6_{ \pm 0.2}$ \\
\hline$\delta-\mathrm{HCH}$ & ND & $19_{ \pm 15}^{[29.2]}$ & ND & $4.7 \pm 1.4$ & ND & ND & ND & ND & ND & $2.7^{\mathrm{a}}$ & ND & $0.9_{ \pm 0.2}$ \\
\hline heptachlor & $34.4_{ \pm 0.0}^{[34.4]}$ & $0.4^{\mathrm{a}}$ & ND & $5.8_{ \pm 1.7}$ & $2.0_{ \pm 2.3}^{[3.6]}$ & $0.5_{ \pm 0.0}^{[0.5]}$ & ND & $0.5_{ \pm 0.2}$ & $4.8^{\mathrm{a}}$ & $1.3_{ \pm 0.0}^{[1.3]}$ & ND & $1.4_{ \pm 0.4}$ \\
\hline heptachlor-exo-poxide & ND & $0.6^{\mathrm{a}}$ & ND & $0.1_{ \pm 0.0}$ & $0.7^{\mathrm{a}}$ & $0.7_{ \pm 0.8}^{[1.2]}$ & ND & $0.4_{ \pm 0.1}$ & ND & $2.3^{\mathrm{a}}$ & ND & $0.8_{ \pm 0.1}$ \\
\hline
\end{tabular}

Mean $_{ \pm \mathrm{SD}}^{[\mathrm{max}]} \mathrm{ng} / \mathrm{g} . \mathrm{ND}=$ Not determined.

${ }^{a}$ Analysis from only one sample.

b The concentrations of OCP were not significantly different $(p>0.05)$ between three bird groups.

lipid contents are shown in Table 2. The extracts were cleaned up with concentrated $\mathrm{H}_{2} \mathrm{SO}_{4}$ until the $\mathrm{H}_{2} \mathrm{SO}_{4}$ fraction remained clear, and then packed on an $8 \mathrm{~mm}$ i.d. alumina/silica column from bottom to top with: neutral alumina $(6 \mathrm{~cm}, 3 \%$ deactivated), neutral silica gel $(10 \mathrm{~cm}, 3 \%$ deactivated), $50 \%$ (on a weight basis) $\mathrm{H}_{2} \mathrm{SO}_{4}$ silica $(10 \mathrm{~cm})$, and anhydrous $\mathrm{Na}_{2} \mathrm{SO}_{4}$. Alumina, silica gel, and anhydrous $\mathrm{Na}_{2} \mathrm{SO}_{4}$ were soxhlet extracted $48 \mathrm{~h}$ with dichloromethane and then baked for $12 \mathrm{~h}$ at 250,180 , and $450{ }^{\circ} \mathrm{C}$, respectively, before use. The volume was adjusted to $2 \mathrm{ml}$, and the content was subject to GC analysis. Extracts were injected in the splitless mode on a Thermo Finnigan GC equipped with a ${ }^{63} \mathrm{Ni} \mu$-electron capture detector. Data were collected with the aid of Chemstation. The GC analysis employed a DB-5 MS capillary column $(30 \mathrm{~m} \times 0.25 \mathrm{~mm}$; with a film thickness of $0.25 \mu \mathrm{m}$ ). The $\mathrm{GC}$ column temperature was programmed from $150^{\circ} \mathrm{C}$ to $300^{\circ} \mathrm{C}$ at $8^{\circ} \mathrm{C} / \mathrm{min}$ and held at $300^{\circ} \mathrm{C}$ for $10 \mathrm{~min}$. Injector and detector temperatures were $250{ }^{\circ} \mathrm{C}$ and $300{ }^{\circ} \mathrm{C}$, respectively. The helium carrier and nitrogen make-up gas flow were set at $150{ }^{\circ} \mathrm{C}$ and at $2 \mathrm{ml} / \mathrm{min}$ and $3 \mathrm{ml} / \mathrm{min}$, respectively. All samples were analysed for the following OCPs: 4,4'-dichlorodiphenyldichloroethylene (4,4'-DDE), 4,4'-dichlorodiphenyldichloroethane (4,4'4-DDD), 4,4'4-dichlorodiphenyltrichloroethane $\left(4,4^{\prime}\right.$-DDT), aldrin, dieldrin, $\alpha$-endosulphan, $\beta$-endosulphan, endosulphan sulphate, endrin, endrin aldehyde, $\alpha$-hexachlorocyclohexane $(\alpha-\mathrm{HCH}), \beta$-hexachlorocyclohexane $(\beta-\mathrm{HCH}), \delta$-hexachlorocyclohexane $(\delta-\mathrm{HCH}), \gamma$-hexachlorocyclohexane $(\gamma-\mathrm{HCH})$, and heptachlor and heptachlor-exo-epoxide.

\section{Quality assurance and quality control}

All samples were subjected to strict quality control procedures. For OCP quantification, standard solutions were used to calibrate the instrument daily. Calibration curves based on a set of concentration (5, $10,20,50,100$, and $200 \mu \mathrm{g} / \mathrm{l}$ ) were drawn. Procedural blanks, solvent blanks, and field blanks were analysed using the same procedure as the used for real samples. Standards (donated by Dr Ehrenstorfer $\mathrm{GmbH}$, Germany) were prepared by dissolution in $\mathrm{n}$-hexane at $10 \mathrm{ng} / \mathrm{ml}$. The analyte mixture was spiked into a matrix to determine the method detection 
Table 3 The detection limit, purity, and retention time of each OCP in this study.

\begin{tabular}{|c|c|c|c|}
\hline $\begin{array}{l}\text { Organochlorine } \\
\text { pesticide }\end{array}$ & $\begin{array}{c}\text { Detection } \\
\text { limit (ng/g) }\end{array}$ & $\begin{array}{l}\text { Purity } \\
(\%)\end{array}$ & $\begin{array}{l}\text { Retention } \\
\text { time (min) }\end{array}$ \\
\hline \multicolumn{4}{|l|}{$\Sigma \mathrm{DDT}$} \\
\hline $4,4^{\prime}-\mathrm{DDD}$ & 0.008 & 99.0 & 30.45 \\
\hline $4,4^{\prime}-\mathrm{DDE}$ & 0.0006 & 98.5 & 29.32 \\
\hline $4,4^{\prime}-\mathrm{DDT}$ & 0.15 & 98.5 & 32.12 \\
\hline \multicolumn{4}{|l|}{$\Sigma$ ALD } \\
\hline aldrin & 0.0001 & 99.0 & 25.50 \\
\hline dieldrin & 0.000003 & 98.5 & 23.12 \\
\hline$\alpha$-endosulphan & 0.00001 & 97.0 & 28.38 \\
\hline$\beta$-endosulphan & 0.10 & 98.0 & 30.82 \\
\hline endosulphan-sulphate & 0.02 & 97.0 & 31.98 \\
\hline endrin & 0.0003 & 99.5 & 30.10 \\
\hline endrin aldehyde & 0.08 & 99.0 & 31.14 \\
\hline \multicolumn{4}{|l|}{$\Sigma \mathrm{HCH}$} \\
\hline$\alpha-\mathrm{HCH}$ & 0.000004 & 98.0 & 20.04 \\
\hline$\beta-\mathrm{HCH}$ & 0.00002 & 98.4 & 21.17 \\
\hline$\gamma-\mathrm{HCH}$ & 0.000009 & 98.5 & 21.42 \\
\hline$\delta-\mathrm{HCH}$ & 0.002 & 98.5 & 22.37 \\
\hline \multicolumn{4}{|l|}{$\Sigma \mathrm{CHL}$} \\
\hline heptachlor & 0.00001 & 99.0 & 24.22 \\
\hline heptachlor-exo-epoxide* & 0.000002 & 98.5 & 27.06 \\
\hline
\end{tabular}

* (cis-, isomerB)

limit. The detection limit, purity, and retention time of each reference standard are shown in Table 3. Average surrogate recoveries ranged between $60 \%$ and $120 \%$. The retention time and peaks of each OCP were compared with those of the reference standards; concentration of each OCP was expressed as ng/g liver (wet weight basis). For OCPs which were not detected in procedural blanks, detection limits were calculated as the amount of analyte per sample corresponding to the lowest calibration standard. In all samples, detection limits ranged between 0.01 and $0.5 \mathrm{ng}$. All the chemicals used in the study were of analytical grade and purchased from Merck, Germany. All solvents used in the study were redistilled to purify them and to reduce any of their interference effect. The glassware used was baked at $450^{\circ} \mathrm{C}$ for $6 \mathrm{~h}$ before use.

\section{Data analysis}

One-way ANOVA was employed to evaluate differences in the concentrations of OCPs between three bird groups using the SPSS 17.0 statistical software. When significant $F$-values were obtained, differences between individual means were tested using the least significant different test (LSD) at $p<0.05$.

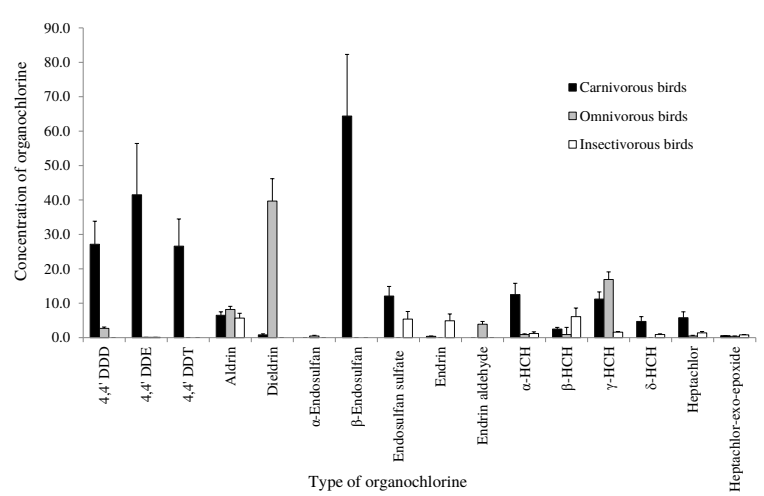

Fig. 2 Concentrations of different OCP isomers in each trophic level of birds in the Boraphet wetland.

\section{RESULTS}

OCPs were detected in the livers of all three groups of birds: carnivores, omnivores, and insectivores (Fig. 2). Total dichlorodiphenyltrichloroethane ( $\Sigma D D T: 4,4^{\prime}$-DDE, 4,4'-DDD, and 4,4'-DDT, $95 \pm 19 \mathrm{ng} / \mathrm{g}$ ) and total aldrin ( ALD: aldrin, dieldrin, $\alpha$-endosulphan, $\beta$-endosulphan, endosulphan sulphate, endrin, and endrin aldehyde, $84 \pm 19 \mathrm{ng} / \mathrm{g}$ ) accumulated most followed by total hexachlorocyclohexane $(\Sigma \mathrm{HCH}: \alpha-\mathrm{HCH}, \beta-\mathrm{HCH}, \delta-\mathrm{HCH}$, and $\gamma-\mathrm{HCH}, 30.9 \pm 4 \mathrm{ng} / \mathrm{g}$ ) and total chlordane compounds ( $\Sigma$ CHL: heptachlor and heptachlor-exo-epoxide, $5.9 \pm 1.7 \mathrm{ng} / \mathrm{g}$ ) successively (Fig. 2); but the concentrations of all OCP groups were not different between three bird types $(p>0.05)$. However, when all 16 OCPs analysed were considered individually, $\beta$-endosulphan, an ALD isomer, accumulated at the highest concentrations (Fig. 2). This suggested continual or extensive use of $\beta$-endosulphan in agriculture around the wetland ${ }^{18}$, despite government restrictions on its use. However, the high $\beta$-endosulphan concentration in carnivorous birds (Fig. 2) suggested that biomagnification may also play a role.

The high EDDT accumulation was attributed to 4,4'-DDE, which mainly accumulated in carnivorous birds (Fig. 2). This indicated that biomagnification contributed, besides the extensive use of 4,4'-DDE in agriculture and malaria-control agent ${ }^{19}$. In the present study, the carnivorous yellow bittern, which mainly fed on fish, accumulated the highest $4,4^{\prime}$-DDE and $\beta$-endosulphan levels (Table 2). Omnivorous birds accumulated low concentration of $\Sigma D D T$, but high $\Sigma$ ALD concentrations. The highest ALD level accumulated was for dieldrin in the Purple Swamphen (Fig. 2 and Table 2). Omnivorous birds accumulated moderate concentrations of $\Sigma \mathrm{HCH}$, but extremely low 
$\Sigma$ CHL concentrations (Fig. 2). In insectivorous birds no $\Sigma$ DDT was detected, $\Sigma$ ALD and $\Sigma \mathrm{HCH}$ accumulation were low, and $\Sigma \mathrm{CHL}$ was barely detected (Fig. 2). Only aldrin, endosulphan sulphate, endrin and $\beta-\mathrm{HCH}$ were detected in these birds, all at relatively low levels (Fig. 2). This suggests insecticide usage around this area was modest or conducted carefully.

\section{DISCUSSION}

Variations in the accumulation of contaminants in birds are due to the differences in habitats, food preferences and the capacity to metabolize contaminants ${ }^{16,20}$. Studies of the OCP accumulation in liver were carried out since this organ is an active site for contaminant biotransformation ${ }^{21}$. The OCP accumulation pattern observed was similar to that reported in previous studies elsewhere ${ }^{20,22-25}$, and reflected the extent to which each OCP was utilized in agricultural areas around the Boraphet wetland. $\Sigma$ DDT and $\Sigma$ ALD were used extensively, $\Sigma \mathrm{HCH}$ only moderately, while, the use of $\Sigma \mathrm{CHL}$ was from mining. The illegal use of $\beta$-endosulphan to control the golden apple snail (Pomacea sp.) in paddy fields has been reported ${ }^{10}$. Predominant accumulation of 4,4'-DDE in carnivorous birds was consistent with other studies which found it to be the most frequent OCP detected in wild bird tissues due to its high persistence and lipophilicity ${ }^{26-28}$. $\mathrm{EHCH}$ contamination was moderate (Fig. 2). Among the four $\mathrm{HCHs}$, the lindane $(\gamma-\mathrm{HCH})$ isomer accumulated the most; similar to the findings of Sakellarides et $\mathrm{al}^{29}$.

Nevertheless, concentrations of all OCPs detected in the present study are lower than those reported previously in the tissues of birds in the Boraphet wetland ${ }^{30}$. Additionally EDDT concentrations were lower than those reported in some waterbird species from Orissa, India; e.g., Eurasian Spoonbill, Northern Shoveler, and Ruff ${ }^{31}$. The decline in OCP contamination in the Boraphet wetland may be due to the increased of restrictions on nearby OCP agricultural use.

The risk of OCP contamination of birds depends on their trophic position. Carnivorous birds in both the present and previous studies ${ }^{16,32}$ were found much more contaminated with OCPs than omnivorous or insectivorous birds (Fig. 2). Similar results were also reported in the liver of birds collected from the coastal area of Campanis, Italy ${ }^{28}$. Birds that feed exclusively on fish have been shown to be at higher contamination risk than birds those feeding at lower trophic levels due to their low monooxygenase activity, resulting in lower biotransformation of xenobiotics and subsequent biomagnification ${ }^{1,33,34}$.

\section{CONCLUSIONS}

The samples of a particular species from different locations were analysed and reported as one group. The present study indicated that birds in the Boraphet wetland are still contaminated with moderate levels of OCPs, with carnivorous birds being at greatest risk due to their high trophic level. Although OCP accumulation of birds was lower than previously reported, regular monitoring of OCP contamination remains essential to ascertain OCP usage in agricultural activities around the Boraphet wetland being properly conducted.

Acknowledgements: We thank the officers of Bueng Boraphet Wildlife Research Station and the Surveillance and Protection of All Viruses in Wild Bird Programme of the Department of National Parks Wildlife and Plant Conservation for assistance during data collection. We are grateful to the Department of National Parks, Wildlife and Plant Conservation, Ministry of Natural Resources and environment, for granting permission to conduct field work and collect samples in the Boraphet wetland. Many thanks also go to Philip D. Round, Department of Biology, Mahidol University for critically editing the manuscript. Finally, we acknowledge Mahidol University and the ADB project of the Mahidol University for financial support of this work.

\section{REFERENCES}

1. Fossi MC, Casini S, Marsili L (1999) Nondestructive biomarkers of exposure to endocrine disrupting chemicals in endangered species of wildlife. Chemosphere 39, 1273-85.

2. Bitman J, Cecil H, Fries GF (1970) DDT-induced inhibition of avian shell gland carbonic anhydrase: a mechanism for thin eggshells. Science 168, 594-6.

3. Peakall DB (1994) DDE-induced eggshell thinning: an environmental detective story. Environ Rev 1, 13-20.

4. Lundholm CD (1997) DDE-induced eggshell thinning in birds: effects of $\mathrm{p}, \mathrm{p}^{\prime}$-DDE on the calcium and prostaglandin metabolism of the eggshell gland. Comp Biochem Physiol C 118, 113-28.

5. Pyle P, Sydeman WJ, McLaren E (1999) Organochlorine concentrations, eggshell thickness, and hatchability in seabirds off Central California. Waterbirds 22, 376-81.

6. Fry M, Toone CK (1981) DDT-induced feminization of gull embryos. Science 213, 922-4.

7. Larson JM, Karasov WH, Sileo L, Stromborg KL, Hanbidge BA, Giesy JP, Jones PD, Tillitt DE, et al (1996) Reproductive success, developmental anomalies, and environmental contaminants in double-crested cormorants (Phalacrocorax auritus). Environ Toxicol Chem 15, 553-9.

8. King KA, Krynitsky AJ (1986) Population trends, reproductive success, and organochlorine chemical con- 
taminants in waterbirds nesting in Galveston Bay, Texas. Arch Environ Contam Toxicol 15, 367-76.

9. Keithmaleesatti S, Thirakhupt K, Pradatsudarasar A, Varanusupakul P, Kitana N, Robson M (2007) Concentration of organochlorine in egg yolk and reproductive success of Egretta garzetta (Linnaeus, 1758) at Wat Tan-en non-hunting area, Phra Nakhorn Si Ayuthaya Province, Thailand. Ecotoxicol Environ Saf 68, 79-83.

10. Siriwong W, Thirakhupt K, Sitticharoenchai D, Borjan M, Keithmaleesatti S, Burger J, Robson M (2009) Risk assessment for dermal exposure of organochlorine pesticides for local fishermen in the Rangsit agricultural area, Central Thailand. Hum Ecol Risk Assess 15, 636-46.

11. BirdLife International (2004) Important Bird Areas of Asia: Key Sites for Conservation. BirdLife International, Cambridge.

12. Scott DA (ed) (1989) A Directory of Asian Wetlands. IUCN, Gland, Switzerland.

13. Office of Environmental Policy Planning (2002) An Inventory of Wetlands of International and National Importance in Thailand. Ministry of Science, Technology, and Environment, Bangkok.

14. Thomann RV (1989) Bioaccumulation model of organic chemical distribution in aquatic food chains. Environ Sci Tech 23, 699-707.

15. Hoekstra PF, O’Hara TM, Fisk AT, Borgå K, Solomon KR, Muir DCG (2003) Tropic transfer of persistent organochlorine contaminants (OCs) within an Arctic marine food web from the southern Beaufort-Chukchi Seas. Environ Pollut 124, 509-22.

16. Cid FD, Antón RI, Caviedes-Vidal E (2007) Organochlorine pesticide contamination in three bird species of the Embalse La Florida water reservoir in the semiarid Midwest of Argentina. Sci Total Environ 385, 86-96.

17. Phillips KM, Tarragó-Trani MT, Grove TM, Grün I, Lugogo R, Harris RF, Stewart KK (1997) Simplified gravimetric determination of total fat in food composites after chloroform-methanol extraction. $\mathrm{J} \mathrm{Am} \mathrm{Oil}$ Chem Soc 74, 137-42.

18. Department of Agriculture of Thailand (2006) Report on Survey on the Use of Endosulfan for Controlling Golden Apple Snail in the Paddy Fields. 2nd Meeting on Rotterdam Convention on the Prior Informed Consent Procedure for Certain Hazardous Chemicals and Pesticides in International Trade Chemical Review Committee, Geneva.

19. Thirakhupt K, Sitthicharoenchai D, Keithmaleesatti S, Siriwong W (2006) Organochlorine pesticides and their usages in Thailand: a review. J Sci Res Chula Univ 31, $1-15$.

20. Fossi MC, Massi A, Lari L, Leonzio C, Focardi S, Marsili L, Renzoni A (1995) Interspecific differences in mixed function oxidase activity in birds: A tool to identify species at risk. Sci Total Environ 171, 221-6.

21. Van den Brink NW, Bosveld ATC (2001) PCB con- centrations and metabolism patterns in common terns (Sterna hirundo) from different breeding colonies in the Netherlands. Mar Pollut Bull 42, 280-5.

22. Hela DG, Konstantinou IK, Sakellarides TM, Lambropoulou DA, Akriotis T, Albanis TA (2006) Persistent organochlorine contaminants in liver and fat of birds of prey from Greece. Arch Environ Contam Toxicol 50, 603-13.

23. Scharenberg W (1991) Cormorants (Phalacrocorax carbo sinensis) as bioindicators for chlorinated biphenyls. Arch Environ Contam Toxicol 21, 536-40.

24. Weseloh DV, Hamr P, Bishop CA, Norstrom RJ (1995) Organochlorine contaminant levels in waterbird species from Hamilton Harbour, Lake Ontario: an IJC area of concern. J Great Lake Res 20, 277-88.

25. Goutner V, Becker PH, Liordos V (2011) Organochlorines and mercury in livers of great cormorants (Phalacrocorax carbo sinensis) wintering in northeastern Mediterranean wetlands in relation to area, bird age, and gender. Sci Total Environ 409, 710-8.

26. Newton I, Wyllie I, Asher A (1993) Long-term trends in organochlorine and mercury residues in some predatory birds in Britain. Environ Pollut 79, 143-51.

27. Hoshi H, Minamoto N, Iwata H, Shiraki K, Tatsukawa R, Tanabe S, Fujita S, Hirai K, Kinjo T (1998) Organochlorine pesticides and polychlorinated biphenyl congeners in wild terrestrial mammals and birds from Chubu region, Japan: interspecies comparison of the residue levels and compositions. Chemosphere 36, 3211-21.

28. Naso B, Perrone D, Ferrante MC, Zaccaroni A, Lucisano A (2003) Persistent organochlorine pollutants in liver of birds of different trophic levels from coast area of Campania, Italy. Arch Environ Contam Toxicol 45, 407-14.

29. Sakellarides TM, Konstantinou IK, Hela DG, Lambropoulou D, Dimou A, Albanis TA (2006) Accumulation profiles of persistent organochlorines in liver and fat tissues of various waterbird species from Greece. Chemosphere 63, 1392-409.

30. Umchang A (1984) Pesticide residues in some birds at Borapet reservoir, Nakorn Sawan Province. MSc thesis, Kasetsart Univ [in Thai].

31. Dhananjayan V (2012) Organochlorine pesticides and polychlorinated biphenyls in various tissues of waterbirds in Nalabana bird sanctuary, Chilika lake, Orissa, India. Bull Environ Contam Toxicol 89, 197-201.

32. McLane MAR, Dustman EH, Clark ER, Hughes DL (1978) Organochlorine insecticide and polychlorinated biphenyl residues in woodcock wings, 1971-1972. Pestic Monit J 12, 22-5.

33. Moore NW, Walker CH (1964) Organic chlorine insecticide residues in wild birds. Nature 201, 1072-3.

34. Walker CH (1990) Persistent pollutants in fish-eating sea birds - bioaccumulation, metabolism and effects. Aquat Toxicol 17, 293-324. 